Ethiopian Journal of Environmental Studies \& Management 9(3): 303 - 314, 2016.

ISSN:1998-0507

doi: http://dx.doi.org/10.4314/ejesm.v9i3.5

Submitted: December 13, 2015

Accepted: May 03, 2016

\title{
OXIDATIVE STRESS POTENTIAL OF LEAD-ZINC MINING ON SELECTED PLANTS GROWING IN ISHIAGU, NIGERIA
}

\author{
OGBONNA, C.E., ${ }^{1}$ ENETE, I.C., ${ }^{2}$ UGBOGU, O.C., ${ }^{3}$ OKEKE, C.U., ${ }^{4}$ OTUU, F.C. 5 AND \\ *UGBOGU, A.E. 6 \\ ${ }^{1}$ Department of Environmental Resource Management, Abia State University, Uturu \\ ${ }^{2}$ Department of Geography and Meteorology, Nnamdi Azikiwe University, Awka \\ ${ }^{3}$ Department of Microbiology, Federal University, Wukari \\ ${ }^{4}$ Department of Botany, Nnamdi Azikiwe University, Awka \\ ${ }^{5}$ Environmental Research Unit, Department of Pharmaceutics, University of Nigeria, \\ Nsukka \\ ${ }^{6}$ Department of Biochemistry, Abia State University, Uturu
}

\begin{abstract}
The study evaluated some biochemical and physiological properties of selected plants growing in the Ishiagu lead-Zinc mining area, Nigeria, in order to assess oxidative stress. Using sampling without replacement, twelve plants were randomly selected from the thirty five identified. Control samples were collected from a non-mining area about twenty five $\mathrm{km}$ away from the study area. Results showed that statistically significant differences were not found between sites with respect to biochemical parameters (ascorbic acid content, $\mathrm{pH}$, total chlorophyll content and relative water content) at $p>0.05$. Physiological parameters (abaxial and adaxial stomata pore size) showed significant difference between site at $p>0.05$. With respect to plants, values for all parameters were statistically significant at $p>0.05$ except for relative water content, possibly due to stomatal occlusion from particulate contamination at the mining area. The lower mean values for $\mathrm{pH}$, total chlorophyll content, and stomata pore size, and the higher mean ascorbic acid values of plants at the mining area is suggestive of oxidative stress from heavy metal accumulation. Stress is very likely to have less potential of mitigating air pollution and providing other environmental services. Such plants also suffer from compromised nutritive and phytotherapeutic values, as well as being potential sources of pollutant intoxication of man and animals through dietary origin.
\end{abstract}

Key Words: Heavy metals, Plants, Physiochemical status, Oxidative stress, Health risks

\section{Introduction}

Mining is an important source of heavy metal contamination of the environment (Singh et al., 2005). Heavy metals are known to contaminate areas surrounding mine sites (Humphries,
2007) as well as pose serious threats to ecosystems and to human health (Duruibe et al., 2007). The sources of contamination include mine tailings, heap leach areas, mine effluents, active and abandoned pits and spoil banks. Plants

*Corresponding Author: Ugbogu, A.E.

Email: amasryal@yahoo.com 
Oxidative Stress Potential of Lead-Zinc Mining on Selected Plants................. OGBONNA et al.

contaminants due to their great ability to adapt to variable chemical properties of the environment and have been described by Kabata-Pendias and Pendias (1984) as intermediate reservoirs through which contaminations from soil and partly from water and air move to man and animals. The main sources of trace elements or heavy metals to plants according to Vousta et al. (1996) are soil, atmosphere (through rain and dust) and nutrient solution, from which they are taken up by roots or foliage. Lorenz et al. (1997) observed that plants in the vicinity of metal mining sites are exposed to atmospheric deposition of particulate and gaseous matter generated by mining activities.

Plant responses to high metal accumulation in soil involve two important mechanisms, namely: accumulation and exclusion. Accumulation is the active uptake of metals and subsequent detoxification in above ground tissue while exclusion involves the maintenance of a constant concentration of heavy metals in the shoots regardless of soil loading (Baker, 1981). It has been suggested by KabataPendias and Pendias (1984) and Alloway (1990) that the rate of uptake, accumulation or translocation of heavy metals in plants vary with plant species, organic matter content and binding capacity. Lynbun and Tychinin (2007) noted that some plants have developed stable forms that can tolerate soils containing high concentrations of heavy metals. Three categories of metal tolerating plants are described by Ghosh and Singh (2005). These are excluders, indicators and hyperaccumulators. Excluders largely restrict metals to their roots while hyperacummulators can shoots and leaves (Cunningham and Ow, 1996; Chaudhry et al., 1998).

Heavy metals are involved in a number of biochemical reactions in plants thus drawing attention on their toxicity potential. An important toxicity mechanism of heavy metals in the view of Cho and Park (2000) is their ability to bind oxygen, nitrogen and sulphur atoms in plant cell, thereby inactivating key enzymes that bind the cisteine. Enzyme inactivation can also result from the substitution of one metal ion with another in the molecule. An example of which is the substitution of $\mathrm{Ca}^{2+}$ with $\mathrm{Cd}^{2+}$ which inhibits phospoesterase cell activity (Rivetta et al., 1997).

Garg and Singlar (2011) and Ozdener and Kutbay (2011) emphasize that heavy metals are abiotic stress factors to plants, affecting and altering their morphological and biochemical status. These changes are particularly linked to non essential heavy metals such as lead and cadmium. This category of metals, directly or indirectly affect physiological processes like photosynthesis, respiration, water balance and gas exchange. Toxicity and sensitivity of plants to heavy metals are largely controlled by soil conditions and plants species (Van and Clisjters, 1990).

Plants growing on metal contaminated soils usually show disturbed water balance (Sayed, 1997). Metals also cause oxidative stress in plants, referring to cellular damage by the active forms of oxygen such as superoxides and hydrogen peroxide (Kappus, 1985). Oxidative stress may result from high heavy metal load which stimulates the formation of free radicals and reactive oxygen species (Dietz et al., 1999). In plants, the antioxidant system gives crucial protection against oxidative 
damage (Noctor and Foyer, 1985). Toxic metals can also induce visible stress symptoms in plants. These phytotoxicity symptoms include chlorosis, necrosis, leaf epinasty, death of older leaves and biomass reduction (Lagriffoul et al., 1998; Adraino 2001).

In the study area, lead and zinc mining has been going on for over fifty years, and in recent times has been intensified. Obiekezie (2005), Nwaugo et al., (2007) and Ogbonna et al., (2015) reported high levels of heavy metals in soils in the vicinity of metal mines. Nwaugo et al. (2008) also reported that microbial diversity and soil enzymatic activities were significantly depressed in metal contaminated soils in Ishiagu. The accumulation of heavy metals by staple tubers in Ishiagu was carried out by Onyedike and Nwosu (2008). Leaf epidermal studies have been carried out in the study area by Ogbonna et al. (2013) but this should be extended to cover other plant parameters. Generally, the physiochemical status of plants in the study area has received little research attention. This study aims at bridging this gap.

There is a renewed interest in the importance of tropical plants in ethnomedical management of myriads of tropical diseases, in addition to the many environmental services they provide. Sustained phytotherapeutic efficacy and nutritional values of plants depend on the quality and quantity of secondary metabolites. When the secondary metabolites are attenuated by oxidative stress, the plants' ethnomedical, food value and environmental service potential will be affected.

Studies have linked many antioxidants and therapeutic properties of plants to flavonoids, ascorbic acids, phenolic compounds, and other secondary metabolites (Cook, et al., 1996). These phytocompounds are metal pollutant sensitive, as heavy metals alter their biochemical configurations, limiting their bioavailability for therapeutic and other functions.

The present study is intended to evaluate the effects of the lead-zinc mining activities in some physicochemical properties of plants namely, ascorbic acid content, total chlorophyll content, relative water content, $\mathrm{pH}$ and stomata pore size. These properties are known indicators of oxidative stress.

\section{Materials and Methods \\ Study Area}

Ishiagu (latitudes $5^{\circ} 52^{\prime}$ to $5^{\circ} 60^{\prime} \mathrm{N}$ and longitudes $7^{\circ} 30^{\prime}$ to $7^{\circ} 37^{\prime} \mathrm{E}$ ), is in Ebonyi State, South Eastern Nigeria. Mean annual rainfall ranges from $1750 \mathrm{~mm}$ to $2000 \mathrm{~mm}$ and mean annual temperature is about $27^{\circ} \mathrm{C}$. The study area is located in the tropical rainforest region. Solid mineral mining and agriculture are the main economic activities in the study area.

\section{Sample Collection}

Leaves samples were collected from plants in a mining site located at 05.55.695N and 007.29.909E in the study area. Using a sampling ratio of $1: 3$ without replacement twelve plants species namely, Adiantum caudatum, Alchornea cordifolia, Andropogon tectorum, Centrosema pubescens, Chromolaena odorata, Clotalaria retusa, Imperata cylindrica, Ipomoea asarifolia, Millettia aboensis, Urena lobata, Vernonia ambigua and Vitex doniana, were randomly selected out of thirty-five plants identified in the study area. Control samples were collected in Uturu 
community around the botanical garden of Abia State University, Uturu. Samples were immediately sent to the laboratory in a heat proof container. Samples were collected in June, 2012.

\section{Laboratory Analysis}

Plant (leaf) physiochemical parameters analysed were ascorbic acid content, chlorophyll content, $\mathrm{pH}$, percentage relative water content and stomata pore diameter (adaxial and abaxial).

\section{Determination of Ascorbic Acid Content}

This was determined according to Bajaj and Kaur (1981) method, using spectrophotometer. One gram of the leaf sample was treated with $4 \mathrm{ml}$ of oxalic acid - EDTA extracting solution in a test tube. Then $1 \mathrm{ml}$ of orthophosphoric acid was added followed by $1 \mathrm{ml}$ of $5 \%$ $\mathrm{H}_{2} \mathrm{SO}_{4}$ and $2 \mathrm{ml}$ of ammonium molybdate, and then $3 \mathrm{ml}$ of water. The solution was allowed to stand for 15 minutes after which the absorbance at $760 \mathrm{~nm}$ was measured. The concentration of ascorbic acid was extrapolated from a standard ascorbic acid curve.

\section{Determination of Chlorophyll Content}

This was determined after Arnon (1949). Exactly $3 \mathrm{~g}$ of the leaf sample was blended and then extracted with $10 \mathrm{ml}$ of $80 \%$ acetone, left for 15 minutes and the liquid portion decanted and centrifuged at 2,500 rpm for 3 minutes. The supernatant was collected and its absorbance measured at $663 \mathrm{~nm}$ using spectrophotometer.

\section{Determination of Leaf $\mathrm{pH}$}

Leaf $\mathrm{pH}$ was determined by "direct reading engineering method" (DREM) using a digital $\mathrm{pH}$ meter. The leaf extract was made by cold maceration of the leaf with de-ionised water, filtered through an ashless filter and the filtrate used for $\mathrm{pH}$ determination. The $\mathrm{pH}$ meter was precalibrated before it was used with buffer solution of $\mathrm{pH} 4$ and 9. The $\mathrm{pH}$ electrode was carefully dipped into the filtrate in a $10 \mathrm{ml}$ beaker. The value displayed on the Crystal Liquid Panel (CLD) was taken as the true $\mathrm{pH}$ value. The exercise was triplicated and the average of the three readings was used.

\section{Determination of Percentage Relative Water Content (RWC)}

This was determined using the method described by Singh (1977). Fresh leaf sample was weighed and recorded as Fresh Mass (FM). It was floated in distilled water inside a closed petri dish at room temperature for 24 hours. At the end of the incubation period, the leaf sample was wiped dry gently with blotted paper and re weighed to obtain the Turgid Mass (TM). It was then placed in a preheated oven at $80^{\circ} \mathrm{C}$ for 48 hours. Thereafter the leaf was weighed to obtain the Dry Mass (DM). The relative water content was calculated using the formula:

$$
R w c=\left(\frac{F M-D M}{T M-D M}\right) 100
$$

Where;

$\mathrm{FM}=$ Fresh mass

$\mathrm{DM}=$ Dry mass

$\mathrm{TM}=$ Turgid mass.

\section{Determination of Stomata Pore Size Preparation of Samples}

Foliar epidermis of the adaxial (upper surface) and abaxial (lower surface) surfaces of the leaf samples were prepared by impression technique method. The slide was viewed under the light microscope at different magnifications and photomicrographs were taken with Zeiss light microscope with MC'35 Camera for $53 \mathrm{~mm}$ film at $\mathrm{x}$ 100specific magnification. Measurement 
of pore diameter was done with an ocular micrometer.

\section{Statistical Analysis}

Minitab version 14 was used in computing analysis of variance at $95 \%$ confidence level.

\section{Results}

The result of plant physiochemical properties are shown on Table 1. At the study area, plant $\mathrm{pH}$ ranged from 4.65 in Vernonia doniana to 6.90 in Chromolaena odarata, Ipomoea asarifolia and Urena lobata with a mean of 5.6 while at the control site, ranged from 4.64 in Vernonia doniana to 6.19 in Chromolaena odorata with a mean of 5.9. Relative water content at the study area ranged from $12.72 \%$ in Vernonia doniana to $84.31 \%$ in Chromolaena odorata with a mean of $39.25 \%$ while at the control, it ranged from $4.25 \%$ in Adiantum caudatum to $77.78 \%$ in Andropogon tectorum with a mean of $33.52 \%$.

Stomata pore diameter (abaxial) varied from $0.1 \mathrm{um}$ in Imperata cylindrica, Urena lobata and Vernonia ambigua to $0.4 \mu \mathrm{m}$ in Vitex doniana with mean of 0.21 um at the study area, while at the control it varied from $0.1 \mu \mathrm{m}$ in Andropogon tectorum to $0.5 \mu \mathrm{m}$ in Vitex doniana with a mean of $0.28 \mathrm{um}$. Stomata pore diameter (adaxial) varied from $0.1 \mu \mathrm{m}$ in Adiantum caudatum and Andropogon tectorum to $0.4 \mu \mathrm{m}$ in Ipomoea asarifolia and Vitex doniana with a mean value of $0.26 \mathrm{um}$ at the study area. At the control, it varied from $0.2 \mu \mathrm{m}$ in A. cordifolia, Andropogon tectorum and Vernonia ambigua to $0.5 \mu \mathrm{m}$ in
Ipomoea asarifolia and Vitex doniana with a mean of 0.32 um.

There was no significant difference in $\mathrm{pH}$ between the control and study area (pvalue $=0.291>0.05)$. However significant differences exist in the $\mathrm{pH}$ for the various plant samples ( $\mathrm{p}$-value $=$ $0.016<0.05)$. Chlomolaena odorata had the highest mean $\mathrm{pH}$ value of 8.05 followed by Ipomoea ascarifolia and Urena lobata with mean values 6.62 and 6.56 respectively.

There was a significant difference in the ascorbic acid and chlorophyll contents of the various plant samples ( $p$ value $=0.026<0.05)$, where mean Ipomoea asarifolia $=6.85>$ mean Centrosema pubecens $=6.13>$ mean Urena lobata $=5.94>$ mean Vitex doniana $=5.91>$ mean Millettia aboensis $=5.76>$ mean Alchornea cordifolia $=$ $5.74>$ mean Chromolaena odorata $=5.61$ $>$ mean Vernonia ambigua $=5.61>$ mean Imperata cylindrica $=5.56>$ mean Clotalaria retusa $=5.30>$ Andropogon tectorum $=5.28>$ mean Adiantum caudatum $=4.77$. Significant difference exists between the magnitude of ascorbic acid and chlorophyll contents (pvalue $=0.00<0.05)$. Mean chlorophyll value $=10.72>$ mean ascorbic acid value $=1.27$. There was no significant difference in ascorbic acid and chlorophyll values between the study area and control ( $\mathrm{p}$ - value $=0.06>0.05$ ), between sites ( $\mathrm{p}$-value $=0.8>0.05)$ and among the various plant samples (pvalue $=0.48>0.05$ ) with respect to relative water content. 
Table 1: Plant Physiochemical Properties

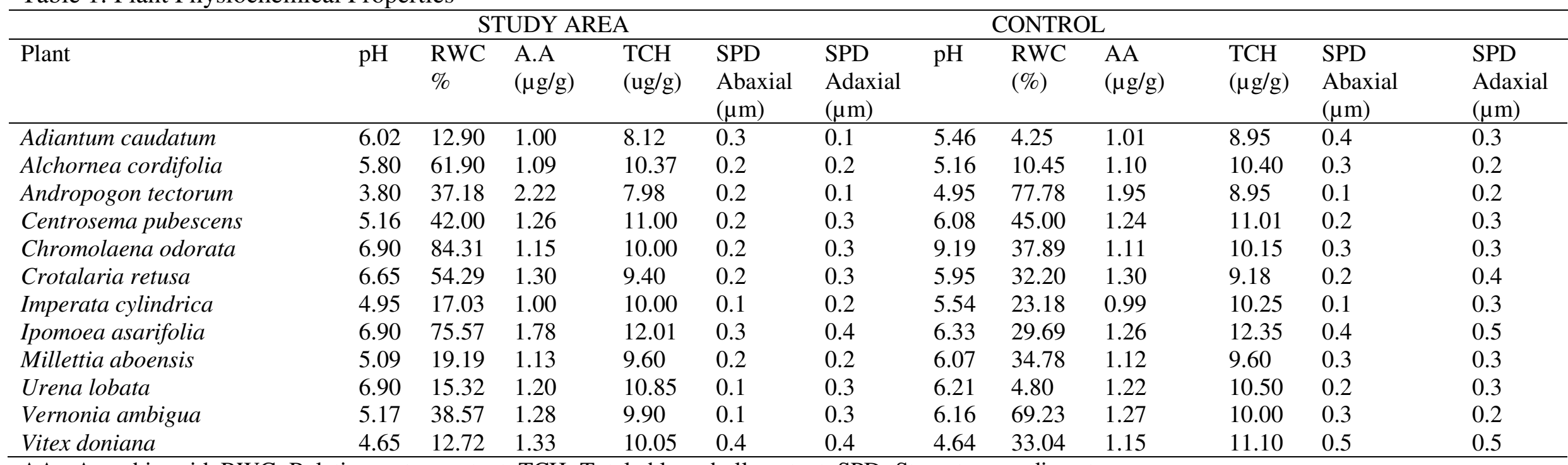

$\mathrm{AA}=$ Ascorbic acid, RWC=Relative water content, $\mathrm{TCH}=$ Total chlorophyll content, $\mathrm{SPD}=\mathrm{Stomata}$ pore diameter. 
For stomata pore diameter, significant difference was found between pore diameter (abaxial and adaxial) among the various plants ( $\mathrm{p}$-value $=0.00<0.05$ ) . The highest mean value for stomata pore diameter occurred in Vitex doniana (Mean $=0.45 \mu \mathrm{m})$ followed by Ipomoea asarifolia $($ Mean $=0.4 \mu \mathrm{m})$ while the lowest mean values occurred in Andropogon tectorum $($ Mean $=0.15 \mu \mathrm{m})$. Significant difference existed between stomata pore diameter abaxial and stomata pore diameter adaxial ( $\mathrm{p}$ - value $=$ $0.03<0.05)$. Significant difference was also found between stomata pore diameter (abaxial and adaxial) between the study area and control ( $\mathrm{p}$-value = $0.003<0.05)$.

\section{Discussion}

Plants differ in their ability to take up nutrients at a given $\mathrm{pH}$ level. Plant $\mathrm{pH}$ influences nutrient solubility and uptake in plants and can modify the toxicity of air pollutants (Klumpp et al., 2000.). Generally plants with low $\mathrm{pH}$ are less tolerant of pollution than those with high pH (Singh and Verma, 2007). Therefore, it is likely that all plants at the study site, with the exception of Chromoleana odorata and Ipomoea asarifolia both of which have $\mathrm{pH}$ of 6.9 are susceptible to heavy metal related pollution.

In plants, ascorbic acid, a natural antioxidant is important for and stress tolerance (Pant and Tripathi, 2011). It maintains the stability of cell membranes (Keller et al., 1977) and activates plant defence mechanisms (Arora et al., 2000). In stressed environments such as metal contaminated sites, higher amounts of ascorbic acid are produced by plants (Pant et al., 2011). Although there was no significant difference in ascorbic acid content between study area and control, mean content of ascorbic acid was higher at the study area. Only three plants namely Adiantum caudatum, Alchornea cordifolia and Urena lobata had higher ascorbic acid levels at the control site (table 1). Ascorbic acid level in plants screened were however lower than those obtained by Pant et al. (2011) and Pant and Tripathi (2011) for different plants.

Chlorophyll content of plants is a measure of environmental stress (Singh and Verma, 2007). Heavy metals interfere with chlorophyll synthesis in plants (Van and Clijsters, 1990). (Stobart et al. (1985) and Oncel et al. (2000) reported that chlorophyll content decreased with increase in metal concentration in plants. Changes in chlorophyll pigment content have also been linked to visual symptoms of plant illness and photosynthetic activity (Parekh et al., 1990). There was no significant difference in chlorophyll content of plant species studied with respect to site. However using plant as a factor, significant differences exist in chlorophyll content. On the whole, chlorophyll content was generally higher at the control. C. retusa and $V$. ambigua were the only plants with lower chlorophyll content at the control. Chlorophyll content in this study was higher than what was obtained by Pandey and Tripathi (2011) and Pant and Dwivedi (2011) for different plants.

Heavy metals may interfere with water balance and content. Sayed (1997) observed that cadmium treated plants at higher concentration had lower relative water content than control plants. However, our study showed that there was no significant difference in RWC of the various plants or between sites. Reduction in RWC or leaf turgidity as a result of heavy metal induced stress has also been reported Barcelo et al. (1986). This situation has been attributed to increase in resistance to water flow in the 
stem and alterations of cell wall properties (Poshenrieder et al., 1989).

A possible reason for the observation in relative water content of plants is stomata occlusion by particulate deposition on leaves. This masks the stomata thereby decreasing transpiration rates or water loss. Particulates are usually generated during soil excavation in mining area by heavy equipment. Further, vegetation destruction and bare surfaces usually associated with open cast mining, the mining method used at the study area. This predisposes soil surface to wind erosion and the subsequent spreading of particulate contaminants by air borne dust.

Heavy metal presence has various effects on plant leaves including reduction in leaf area, stomata closure; low stomata index and pore diameter (Sayed, 1997; Perfus-Barbeoch, 2002; Weryszko-Chmielewska and Chwil, 2005). Stomata closure may have contributed to the observed high RWC in plants at the study area since reduced stomata pore diameter implies tendency towards closure. The consequence is reduction in transpiration rate, thus increasing water retention (PerfusBarbeoch, 2002). The results for stomata pore diameter agree with the findings of Sayed (1997) who worked on heavy metal (cadmium) impact on Carthisamus tinctorius and Shi and Cai (2009) for abaxial side. Reduction in stomata size can have other negative impacts on leaves including efficiency of transpiration, photosynthesis and gas exchange (Kasim, 2005) as well as on plant biomass Shi and Cai (2009).

Lead-zinc mining activities generally involve the removal of overburden, drilling, blasting and crushing of stones. The various impacts produced by these operations are both size and location dependent. Manifestations of specific impacts are on the air, water, soil, earth surface, flora, fauna and human beings (Areola, 1991; Enger and Smith, 2002). Apart from land degradation, other negative impacts of mining include swamp creation, deterioration of ground water, erosion of soil, noise from rock blasting, generation of dust, smoke and fumes, production of noxious gases and earth vibration. Suspended particulate matter is quite significant among all pollutants originating from such operations (USEPA, 1996). While man and animals may move away from the source of negative impacts, plants are relatively immobile and therefore are the major recipient of environmental abuse, leading to alteration in physiochemical properties and induction of oxidative stress (Otuu et al., 2015).

Ishiagu inhabitants, especially those in the rural communities rely extensively on herbal medicines as Ebonyi State generally is rich in medicinal plants. Medicinal plants growing around the mining sites accumulate these toxic metals (Ogbonna et al., 2015) and hence are, phytopotentially attenuated. Consumers of these plants such as man, game, and grazing animals are exposed to heavy metal contamination through the food chain. Occluded stomata affect transpiration and evaporation, enhancing water retention, turgidity and foliarlysis. This will invariably affect yield, nutritive value and phytoconstituents (Otuu et al., 2015). Plants are primary producers in any eco-system. Their pollution will therefore affect all forms of life in the eco-system. If the intensity and the magnitude of such pollution exceed the plant's restorative ability, defoliation sets in and the fragile dynamic eco-system may break down.

Destruction of the guard cells will expose the plants to destructive herbivores, exacerbating stress in the 
plants, minimizing yield, challenging physiological and biochemical integrity. This leads to decreased nutritive and phytotherapeutic values. Besides, most metals implicated in lead-zinc mining activities are antagonistic to plants' hormones, enzymes and secondary metabolites. They may form stable complexes, thereby limiting their potential for a variety of functions, uses and services.

\section{Conclusion}

Anthropogenic activities such as heavy metal mining have various effects on environmental health. One of such effects is on the biochemistry and physiology of plants species thriving in such environments. In this study, an assessment of $\mathrm{pH}$, ascorbic acid content, total chlorophyll content, relative water content and stomata pore size of plants in a lead-zinc mining area was made. Although significant differences between sites were found in only stomata pore size, higher values of ascorbic acid content and lower values of total chlorophyll content and $\mathrm{pH}$ of plants at the study site is suggestive of oxidative stress as a result of heavy metal contamination. Plants have various uses to man and the environment including reduction and mitigation of air pollution (Beckett et al., 1998; Lakshmi, et al., 2008) and medicinal and pharmacological importance (Burkhill, 1994; Lawal et al., 2011). If plant physiochemical status is compromised, their capability to play these and other roles will be affected. In a situation where such plants are consumed by man, the associated health risk may be adverse.

\section{References}

Adraino, D.C. (2001). Trace Elements in Terrestrial Environments. New York, Springer- Verlag.
Alloway, B.J. (1990). Heavy Metals in Soils. Glasgow, Blackie.

Arnon, D.I. (1949), Copper Enzymes in Isolated Chloroplasts. Polyphenol Oxidase in Beta vulgaris. Plant Physiology, 2: 1-15.

Areola, O. (1991). Ecology of Natural Resources in Nigeria. Aldershot. Avebury Academic Publishing Group.

Arora, A., Siaram, R.K. and Srivaastava, G.C. (2002). Oxidative Stress and Antioxidative Systems in Plants. Current Science, 82: 1227- 1238.

Bajaj, K.L. and Kaur, G. (1981). Spectrophotometric Determination of Ascorbic Acid in Vegetables and Fruits. Analyst, 106: 117-120

Baker, A.J.M. (1981), Accumulations and Excluders - Strategies in the Responses of Plants to Heavy Metals. Journal of Plant Nutrition, 3: 643-654.

Barcelo, J., Cobot, C. and Poschenrieder, C. (1986). Cadmium Induced of Decrease of Water Stress Resistance in Bush Bean Plants (Phaseolus vulgaris L. cv Contender: Effects of Cadmium on Endogenous Abscisic Acid Levels. Journal of Plant Physiology, 125: 27-34.

Chaudhry, T.M., Hayes, W.J., Khan, A.G. and Khoo, C.S. (1998). Phytoremediation- Focusing on Accumlator Plants That Remediate Metal Contaminated Soils. Australian Journal of Ecotoxicology, 4: 37-51.

Cho, U. and Park, J.G. (2000). MercuryInduced Oxidation Stress in Tomato Seedlings. Plant Science, 152: 1-9.

Cook, N.S. and Samman, S. (1996). Flavinoids-Chemistry, metabolism, cardio-protective effect and dietary sources. Journal of Nutritional Biochemistry, 7:66-76. 
Cunningham, S.D. and Ow, D.W. (1996). Promises and Prospects of Phytoremediation. Plant Physiology, 110: 715-719.

Dietz, K.J., Baier, M. and Kramer, U. (1999). Free Radicals and Reactive Oxygen Species as Mediators of Heavy Metal Toxicity in Plants: From Molecules to Ecosystems. Berlin. Springer-Verlag.

Duruibe, J.O., Ogwuegbu, M.O.C. and Egwurugwu, J.N. (2007). Heavy Metal Pollution and Human Biotoxic Effects. International Journal of Physical Sciences, 2: 112-118.

Enger, E.D and Smith, B. F (2002). Environmental Science: A Study of Interrelationship. $8^{\text {th }}$ Edition. New York. McGraw Hill Higher Education

Garg, N. and Singlar, P. (2011). Arsenic Toxicity in Crop Plants: Physiological Effects and Tolerance Mechanisms. Environmental Chemistry Letters, 9: 303-321.

Ghosh, M and Singh, S.P. (2005). A Review of Phytoremadiation of Heavy Metals and Utilisation of its By-products. Applied Ecology and Environmental Research, 3(1):1-18

Humphries, J.A. (2007). Effects of Longterm Metal Contamination on the Structure and Function of Microbial Communities in Soils. Ph.D Thesis. Texas Technical University, Texas.

Kabata-Pendias. A and Pendias, H. (1984). Trace Elements in Soil and Plants. Boca Raton, Florida. CRC Press.

Kappus, H. (1985). Lipid Peroxidation: Mechanisms, Analysis, Enzymology and Biochemical Relevance. In Oxidative Stress. (Ed), H, Sies London. Academic Press.
Kasim, W.A. (2005). The Correlation Between Physiological and Structural Alterations Induced by Copper and Cadmium Stress in Broad Beans (Vicia faba L.). Egyptian Journal of Biology, 7: 2032.

Keller, T. and Schwager, H. (1977). Air Pollution and Ascorbic Acid. European Journal of Pathology, 7: 338-350.

Klummp, P., Furlan, C.M. and Dominigos, M. (2000). Response of Stress Indicators and Growth Parameters of Tibouchima pulchra Exposed to Air and Soil Pollution Near the Industrial Complex of Cubatao, Brazil. The Science of the Total Environment, 246: 79-91

Lagriffoul, A., Mocquot, B., Mench. M. and Vangronsveld, J. (1998). Cadmium toxicity effects on growth, mineral and chlorophyll contents and activities of stress related enzymes in young maize plants (Zea mays L.). Plant and Soil, 200: 241-250.

Lorenz, S.E., Hamon, R.E., Holm, P.E., Domnigues, H.C., Sequeria, E.M., Christensen, T.H. Mc-Grath, S.P. (1997), Cadmium and Zinc in Plants and Soil Solutions from Contaminated Sites. Plant and Soil, 189: 21-31.

Nwaugo, V.O., Obiekezie, S.O. and Etok, C.A. (2007). Post Operational Effects of Heavy Metal Mining on Soil Quality in Ishiagu, Ebonyi State. International Journal of Biotechnology and Allied Science, 2: 242-246.

Nwaugo, V.O., Onyeagba, R.A, Akubugwo, E.I and Ugbogu, O.C (2008). Soil Bacteria Flora and Enzymatic Activities in Heavy Metal Contaminated Soils of 
Ishiagu, Ebonyi State. Biokemistri, 20(2):77-84.

Obiekezie, S.O. (2005), Effects of Mining Activities on Physicochemical and Bacteriological Quality of Water and Soil in Ishiagu Area of Ebonyi State, Nigeria. Unpublished Ph.D Thesis, Abia State Univer., Uturu.

Ogbonna, C.E., Okeke, C.U., Ugbogu, O.C. and Otuu, F.C. (2013). Leaf Epidermal Analysis of Some Plants in the Ishiagu Lead-Zinc Mining Area, South Eastern Nigeria. International Journal of Biosciences, 3(11): 122-128.

Ogbonna, C.E., Otuu, F.C., Ugbogu, O.C., Nwaugo, V.O. and Ugbogu, A.E. (2015). Public Health Implication of Heavy Metal Contamination of Plants Growing in the Lead Zinc Mining Area of Ishiagu, Nigeria. International Journal of Biodiversity and Environmental Science, 7(4): 76-86.

Oncel, I., Keles, Y. and Ustun, A.S. (2000). Interactive Effects of Temperature and Heavy Metal Stress on the Growth and Some Biochemical Compounds in Wheat Seedlings. Environmental Pollution, 107: 315-320.

Onyedike, G.O. and Nwosu, G.U. (2008). Lead, Zinc and Cadmium Accumulation in Root Crops From Mineralized Galena-Sphalerite Mining Areas and Environment. Pakistan Journal of Nutrition, 7: 418-420.

Otuu, F.C., Nwandigwe, A. and Okwuosa, C.N. (2015). Evaluation of Five Medicinal Plants at Gas Flaring Site Using Foliar Photomicroscopy. Journal of Toxicology and Environmental Health Sciences, 7(7): 68-75.
Pant P.P. and Tripathi, A.K. (2010). Effects of Heavy Metals on Morphological and Biochemical Characteristics of Albizia procera (Roxb.) Benth.Seedlings.

International Journal of Environmental Science, 1: 10091018.

Pant, P.P., Tripathi, A.K. and Dwivedi, V. (2011). Effect of Heavy Metals on Some Biochemical Parameters of Sal (Shorea robusta) Seedling at Nursery Level, Doon Valley, India. Journal of Agricultural Science, 2: 45-51.

Parekh, D., Puranik, R.M. and Srivastava, H.S. (1990). Inhibition of Chlorophyll Biosynthesis by Cadmium in Greening Maize Leaf Segments. Biochemie Physiologie der Pflanzen, 186: 239-242.

Perfus-Barbeoch, L. (2002). Heavy Metal Toxicity: Cadmium Permeates Through Calcium Channels and Disturbs the Plant Water Status. The Plant Journal, 32:539-548.

Poshenrieder, C., Gunse, B. and Barcelo, J. (1989). Influence of Cadmium on Water Relations, Stomatal Resistane and Abscisic Acid Content in Expanding Beans Leaves. Plant Physiology, 90: 1365-1371.

Rivetta, A., Negrini, N. and Cocucci, M. (1997). Involvement of $\mathrm{Ca}$ Calmodulin in Cd Toxicity During the Early Phases of Radish (Raphanus sativus) Seed Germination. Plant Cell Environment, 20: 600-608.

Sayed, S. (1997). Effect of Cadmium and Kinetin on Transpiration rate and Stomatal Opening and Relative Water Content in Safflower Plants. Journal of Islamic Academy of Sciences, 10: 73-80. 
Shi, G. and Cai, Q. (2009). Cadmium Tolerance and Accumulation in Eight Potential Energy Crops. Biotechnology Advances, 27: 555561.

Singh, A. (1977). Practical Plant Physiology. New Delhi. Kalyani Publishers.

Singh, A.N., Zeng, D.H. and Chen, F.S. (2005). Heavy metals concentration in re-developing soil of mine spoil under plantation of certain native woody species in dry tropical environment. Indian Journal of Environmental Management, 17,168-174.

Singh, S.N. and Verma, A. (2007). Phytoremediation of Air Pollutants: A Review In Environmental Bioremediation Technology. Singh, S.H and Tripathi, R.D (Eds). Berlin. Springer. Pp 293-314.

Stobart, A.K., Griffinths, W., AmeenBukhari, I. and Sherwood, R.P. (1985). The Effect of $\mathrm{Cd}$ on the Biosynthesis of Chlorophyll in
Leaves of Barley. Physiologia Plantarum, 63: 293-298.

USEPA (1996). Review of National Ambient Air Quality Standards for Particulate Matter: Policy Assessment of Scientific and Technical Information. Report No: EPA452/R-96-013. United States Environmental Protection Agency, Washington DC.

Van, A. and Clijsters, H. (1990). Effects of Metals on Enzymes Activity in Plants. Plant Cell Environment, 13: 195-206.

Vousta, D., Grimanis, A. and Samara, C. (1996). Trace Elements in Vegetables Grown in an Industrial Area in Relation to Soil and Air Particulate Matter. Environmental Pollution, 94 (3):325-335

Weryszko-Chmielewska, E. and Chwil, M. (2005). Lead induced histological and ultrastructural changes in the leaves of soybean (Glycine max (L.) Merr.). Soil Science and Plant Nutrition, 51: 203-212. 